\title{
The efficiency of linear Fresnel reflectors in producing superheated steam for power plant drive
}

\author{
Mokhtar Ghodbane ${ }^{1,2 *}$, Marek Majdak ${ }^{3}$, and Boussad Boumeddane ${ }^{1}$ \\ ${ }^{1}$ Department of Mechanical Engineering, Faculty of Technology, Saad Dahlab University of Blida 1, Blida 09000, Algeria \\ ${ }^{2}$ Renewable Energies Development Unit in Arid Zones (UDERZA), El-Oued 39000, Algeria \\ ${ }^{3}$ Department of Energy, Cracow University of Technology
}

\begin{abstract}
Solar energy is one of the most important sources of renewable energies, which is widely used in many fields, such as electricity production through direct production of superheated steam based on Linear Fresnel Reflector. This study aims to show the optical and thermal behavior of linear Fresnel solar reflectors field directed to the electricity production in El-Oued region at Algeria. Four days of different weather data have been selected to track the change in solar field performance. Numerical optical modeling has shown that the optical performance of the solar field has reached $53.60 \%$, while the thermal study based on the numerical solution of the energy balance equations of the receiver tube proved that the thermal efficiency was $37.3 \%$ and the average thermal loss coefficient was limited between 5.72 and $5.98 \mathrm{~W} / \mathrm{m}^{2} \mathrm{~K}$. As for the superheated steam temperature, the lowest value was recorded in December with a value of $501 \mathrm{~K}$. The results obtained are very compelling and encouraging to invest in this low-cost technology.
\end{abstract}

\section{Introduction}

The current global energy situation illustrates that most countries in the world are very dependent on fossil fuels (oil, gas, and coal) to meet their needs [1]. Hydrocarbons, the dominant energy source, cover $80 \%$ of global energy production. At this speed of exploration and exploitation, the situation of hydrocarbon reserves is extremely worrying and their environmental impact is very alarming $[2,3]$. As an alternative to these concerns, the development and implementation of renewable energy are unavoidable. Unlimited and abundant energy resources exist and must be exploited; The most important are solar energy, wind power, hydropower, geothermal energy, biomass energy, and new hydrogen energy $[4,5]$. The exploitation of these clean and sustainable sources of energy will allow the solution to the energy problem in the world, and at the same time, it will permanently delete all the threats to the environment and human beings. Especially the exploitation of solar energy, which is the basis for the rest of the sources of renewable energies.

Solar energy is very energy efficient. It can be used in many industrial and domestic fields [6-8], as there are many technologies for exploiting it, namely, linear concentrators, point concentrators, flat collectors, photovoltaic cells $[5,9]$. Currently, many studies have shown that using nanoparticles combined with a heat transfer fluid can improve the thermal performance of solar collectors of all kinds [10-13], Because dispersing nanoparticles in working fluids with certain concentrations will allow improving the phenomenon of heat transfer, and currently, several scientific research encourages the use of nanofluids in many industrial fields [14-16].

Currently, solar concentrating technologies (Parabolic trough collectors "PTCs", Linear Fresnel reflectors "LFRs", heliostat field collectors "HFCs" and Parabolic dish collectors "PDCs") have the greatest potential for commercial exploitation in the production of electric energy based on solar energy [17], because their performance is very significant and their returns are guaranteed.

This numerical study aims to produce superheated steam that will be used to produce electricity at power stations using solar Fresnel reflectors. LFRs technology is a very young technology that is very effective and characterized by its low cost [18-20]. This technology is on the way to development, as many modern and discreet scientific research has touched on it, among the most important are the works of Bellos et al. [21-24]. In addition, Bellos conducted a review work on this linear solar reflector, in which he touched on the optical, thermal, and commercial aspects of this technology [19]. Moreover, Barbón et al. have seen many studies on small models of linear Fresnel solar collectors [25-27]. In addition, Ghodbane et al. have conducted numerous experimental and numerical studies on this type of solar collector in the field of water heating [13, 28-32]. On the other hand, Said et al. have conducted a study to demonstrate the optical behavior of the solar collector, which was performed by Ghodbane et al. [18].

* Corresponding author: ghodbanemokhtar39@yahoo.com 
The use of linear Fresnel solar reflectors for the production of electricity by thermodynamic power plants is an increasingly attractive solution. However, the performance of the latter, as well as good producibility for this technology, still need to be studied. In this work, a numerical study will be examined on Fresnel's solar collector, which will be used to produce steam for the power plant in El Oued, Algeria. The geographical coordinates of El-Oued region are 33.605084 North, 6.799574,19, and 62m. Four different climate data days were selected for this study, they are as follows: 21/03/2018, 21/06/2018, 21/09/2018, and $21 / 12 / 2018$. This study is based on performing numerical analysis and simplification of energy balance equations for programming on MATLAB. As it is possible to show everything related to the optical and thermal behavior of the studied solar system, allowing to track the thermal cycle of the steam.

\section{Thermal Modelling of the Receiver System}

The numerical modeling of the performance of the studied solar collector (optical and thermal) is based on the energy balances characterized by the differential equations of the three temperatures: TнтF (for the superheated steam), $\mathrm{T}_{\mathrm{G}}$ (for the glass cover), and $\mathrm{T}_{\mathrm{Ab}}$ (for the receiver tube). These equations vary during the illumination time $(t)$ for a length $(\Delta X)$ of the receiver. The finite difference method in the implicit model was used to analyze and approximate the energy balance equations. The most important element in a linear Fresnel reflector is the receiver tube in which the heat transfer fluid circulates inside. The receiver tube is often made of copper covered with a suitable selective layer and surrounded by a glass cover; it is placed along the focal line of the Fresnel concentrator. The existing thermal exchanges are between the steam, the receiver tube, and the glass cover. The beam radiation reflected by the mirrors falls on the receiver tube, after passing through the glass cover. This incident solar energy absorbed by the receiver tube is not entirely transmitted to the steam, where a part is dissipated in the form of heat loss between the receiver tube and the glass cover, and another part is lost between the glass tube and the ambient air.

\subsection{Energy balance of the receiver tube}

The energy balance equation for the receiver tube is $[2$, 13]:

$$
\begin{aligned}
\rho_{A} \cdot \mathrm{C}_{A} \cdot \mathrm{A}_{A} \cdot \Delta X \frac{\partial T_{A}(\mathrm{X}, \mathrm{t})}{\partial t} & \\
& =q_{\text {absorbed }}(t) \\
& -q_{\text {lost }}(\mathrm{X}, \mathrm{t})-\mathrm{q}_{\text {gain }}(\mathrm{X}, \mathrm{t})
\end{aligned}
$$

The initial conditions of Eq. 1 are $[2,13]$ :

$$
T_{\mathrm{Ab}}(\mathrm{X}, 0)=\mathrm{T}_{\mathrm{amb}}(0)
$$

\subsection{Energy balance of the steam}

The energy balance for the steam flowing through the receiver tube is $[2,13]$ :

$$
\begin{aligned}
\rho_{F} \cdot \mathrm{C}_{F} \cdot \mathrm{A}_{\mathrm{A}, \mathrm{int}} \cdot \Delta X \frac{\partial T_{F}(\mathrm{X}, \mathrm{t})}{\partial t} & \\
& =q_{\text {gain }} \\
& -\rho_{F} \cdot \mathrm{C}_{F} \cdot \mathrm{Q}_{v} \cdot \Delta X \frac{\partial T_{F}(\mathrm{X}, \mathrm{t})}{\partial X}
\end{aligned}
$$

Table 1. Dimension of the studied solar collector.

\begin{tabular}{|c|c|}
\hline Geometric Dimension & Value \\
\hline The outside diameter of the absorber $\left(\mathrm{D}_{\mathrm{A}, \mathrm{ext}}\right)$ & $0.070 \mathrm{~m}$ \\
\hline The inner diameter of the absorber $\left(\mathrm{D}_{\mathrm{A}, \mathrm{int}}\right)$ & $0.065 \mathrm{~m}$ \\
\hline The outside diameter of the glass $\left(\mathrm{D}_{\mathrm{V}, \mathrm{ext}}\right)$ & $0.115 \mathrm{~m}$ \\
\hline The inner diameter of the glass $\left(\mathrm{D}_{\mathrm{V}, \text { int }}\right)$ & $0.109 \mathrm{~m}$ \\
\hline The total length of aperture area $\left(\mathrm{L}_{\mathrm{T}}\right)$ & $89.6 \mathrm{~m}$ \\
\hline Total width of aperture area $\left(\mathrm{W}_{\mathrm{T}}\right)$ & $11.4643 \mathrm{~m}$ \\
\hline
\end{tabular}

The boundary and initial conditions of Eq. 3 are [2, 13]:

$$
\begin{aligned}
& T_{\mathrm{HTF}}(0, \mathrm{t})=413.15 \mathrm{~K} \\
& T_{\mathrm{HTF}}(\mathrm{X}, 0)=413.15 \mathrm{~K}
\end{aligned}
$$

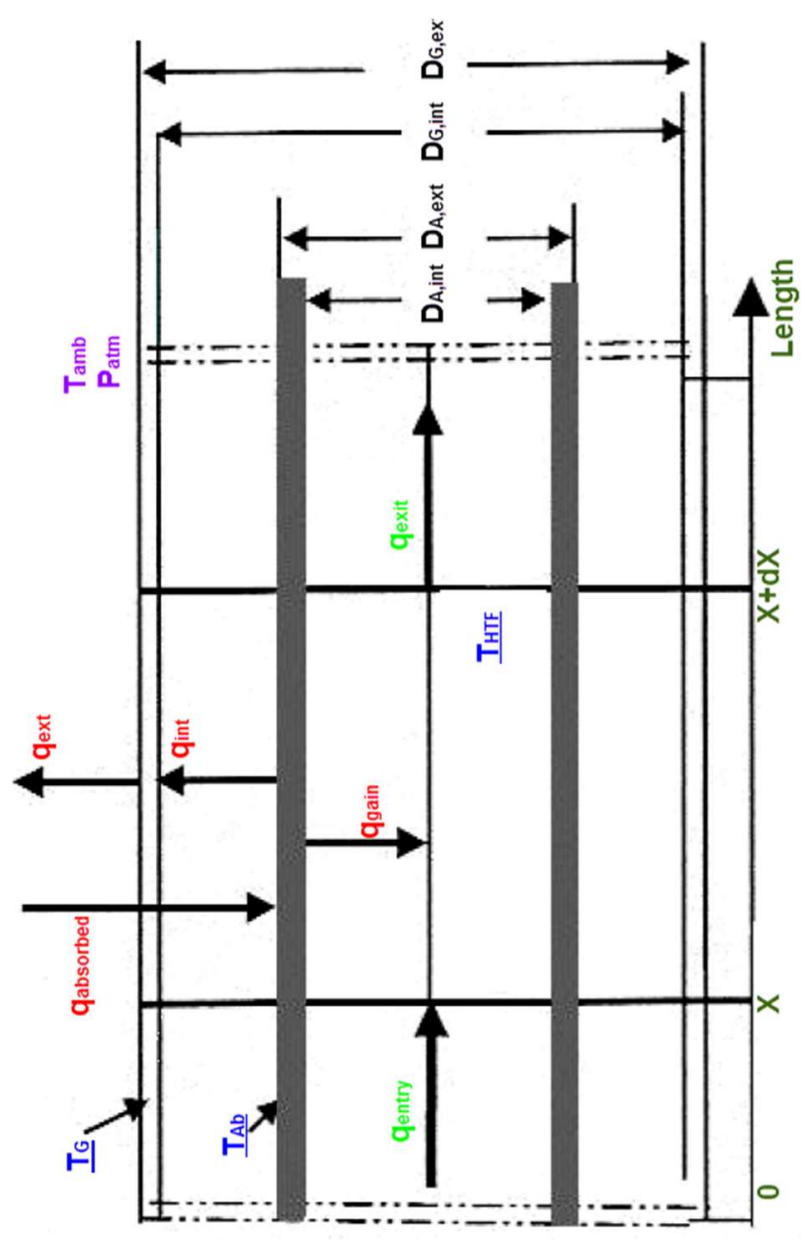

Fig. 1. Thermal behavior on a segment of the receiver tube.

\subsection{Energy balance of the glass cover}

The energy balance equation for the glass cover is [2]:

$$
\rho_{\mathrm{G}} \cdot \mathrm{C}_{G} \cdot \mathrm{A}_{G} \cdot \Delta X \frac{\partial T_{G}(\mathrm{X}, \mathrm{t})}{\partial t}=q_{\mathrm{int}}(\mathrm{X}, \mathrm{t})-\mathrm{q}_{\mathrm{ext}}(\mathrm{X}, \mathrm{t})
$$


Eq. 6 shows the initial conditions of Eq. 5 [2].

$$
T_{G}(\mathrm{X}, 0)=\mathrm{T}_{\mathrm{amb}}(0)
$$

Table 2. Optical characteristics of the studied solar concentrator.

\begin{tabular}{|c|c|}
\hline Parameter & Value \\
\hline Global average optical error $\left(\sigma_{\text {optique }}\right)$ & $03 \mathrm{mrad}$ \\
\hline The reflectance of the mirror $(\rho \mathrm{m})$ & 0.92 \\
\hline Transmissivity of the glass tube & 0.945 \\
\hline Coefficient of absorptions of the absorber $(\alpha)$ & 0.94 \\
\hline The emissivity of the absorber tube $\left(\varepsilon_{\mathrm{Ab}}\right)$ & 0.12 \\
\hline The emissivity of the glass $(\varepsilon \mathrm{G})$ & 0.935 \\
\hline
\end{tabular}

\subsection{Heat loss coefficient}

The absorber tube of a linear Fresnel solar reflector heats up and loses heat to the outside in the form of radiation and convection, where this loss can be characterized by a heat loss coefficient " $\mathrm{U}_{\mathrm{L}},\left(\mathrm{W} / \mathrm{m}^{2} . \mathrm{K}\right)$ ". The coefficient of heat loss $\left(\mathrm{U}_{\mathrm{L}}\right)$ is [33]:

$$
\begin{aligned}
& U_{L}=\left(\frac{1}{C_{1}\left[\frac{T_{\mathrm{Ab}}-T_{\mathrm{amb}}}{1+f}\right]^{\frac{1}{4}}}+\frac{D_{\mathrm{A}, \mathrm{ext}}}{D_{\mathrm{V}, \text { int }} \times h_{W}}\right)^{-1} \\
& +\left(\frac{\sigma\left(T_{A b}^{2}+T_{a m b}^{2}\right) \cdot\left(T_{A b}+T_{a m b}\right)}{\left[A_{1}\right]^{-1}+\left[A_{2}\right]}\right) \\
& \text { where, } \mathrm{A}_{1}=\varepsilon_{A b}-0.04\left(1-\varepsilon_{A b}\right)\left(\frac{T_{A b}}{450}\right) \\
& \text { and } \mathrm{A}_{2}=\left(\frac{D_{A, \text { ext }}}{D_{V, \text { int }}}\left(\frac{1}{\varepsilon_{G}}-1\right)\left(\frac{f}{\varepsilon_{G}}\right)\right) \\
& \text { with, } \mathrm{f}=D_{\mathrm{A} \text {,int }}^{-0.4}\left(1.61+1.3 \varepsilon_{\mathrm{Ab}}\right) h_{W}^{-0.9} \\
& \times \exp \left[0.00325\left(T_{\mathrm{Ab}}-273\right)\right] \\
& \text { and, } \mathrm{C}_{1}=\frac{1.45+0.96\left(\varepsilon_{\mathrm{Ab}}-0.5\right)^{2}}{D_{\mathrm{A}, \text { ext }}\left(\frac{1}{D_{\mathrm{A}, \text { ext }}^{0.6}}+\frac{1}{D_{\mathrm{V}, \text { int }}^{0.6}}\right)^{\frac{5}{4}}}
\end{aligned}
$$

\subsection{Fresnel solar collector performances}

It can express the optical efficiency $\left(\eta_{\text {opt }}\right)$ of the studied concentrator by $[2,13,19]$ :

$$
\eta_{\mathrm{opt}}=\alpha \cdot \tau \cdot \rho_{m} \cdot \gamma \cdot \mathrm{K}_{t}\left(\theta_{t}\right) \cdot \mathrm{K}_{l}\left(\theta_{l}\right)
$$

Eq. 9 gives the thermal efficiency $\left(\eta_{\text {th }}\right)[2,13,19]$.

$$
\eta_{\mathrm{th}}=\eta_{\mathrm{opt}}-\frac{U_{L} \cdot \mathrm{A}_{A} \cdot\left(T_{A}-T_{\mathrm{amb}}\right)}{D N I \times S_{e}}
$$

\section{Results and Discussion}

\subsection{Climatic conditions}

Fig. 2 shows the evaluation of beam radiation "DNI, $\left(\mathrm{W} / \mathrm{m}^{2}\right)$ " according to time for the selected days.

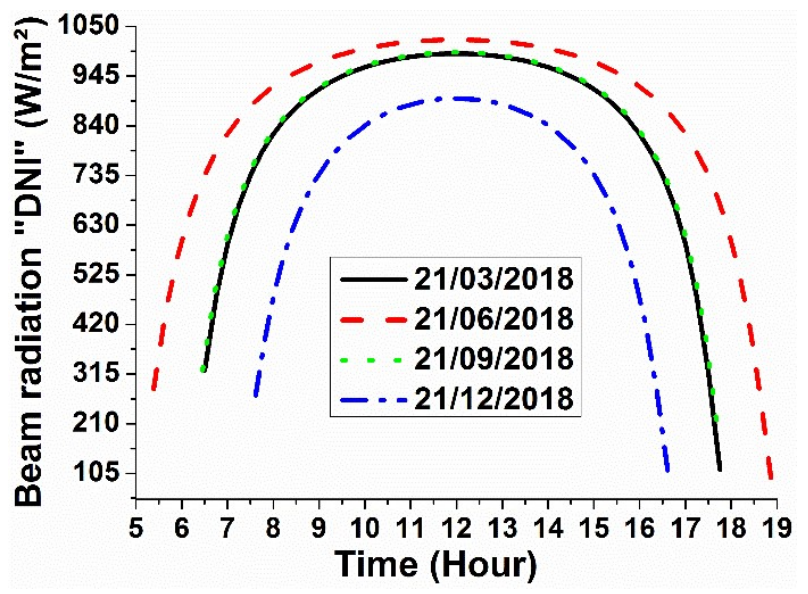

Fig. 2. Variation of beam radiation (DNI).

It is noticeable that the change in beam radiation is logical from sunrise to sunset. The maximum values of solar radiation for the four days starting March through December are as follows: $992.7994 \mathrm{~W} / \mathrm{m}^{2}, 1022.031$ $\mathrm{W} / \mathrm{m}^{2}, 995.1583 \mathrm{~W} / \mathrm{m}^{2}$, and $898.2667 \mathrm{~W} / \mathrm{m}^{2}$. Fig. 2 clearly shows the abundance of the selected area for conducting large quantities of direct solar radiation. This is a positive point for the use of solar energy by constructing solar power powers of various types. According to Ghodbane et al. [2, 9, 13, 29], the climatic conditions of El-Oued region are very suitable for investment in the exploitation of solar energy in many areas (air conditioning and electricity production).

\subsection{Efficiencies assessment}

Generally, the efficiency of the linear Fresnel reflector is the ratio between the useful heat transmitted from the receiver tube to the heat transfer fluid and the incident solar radiation.

As for optical efficiency " $\eta_{\text {opt }}$ ", it is related to the optical properties of solar reflector components and relates to the rate of beam radiation access to the receiver tube. This ratio is evaluated using the intercept coefficient " $\gamma$ ". Fig. 3 illustrates the evaluation of the LFR performances vs. time for the selected days.

a) Optical efficiency.

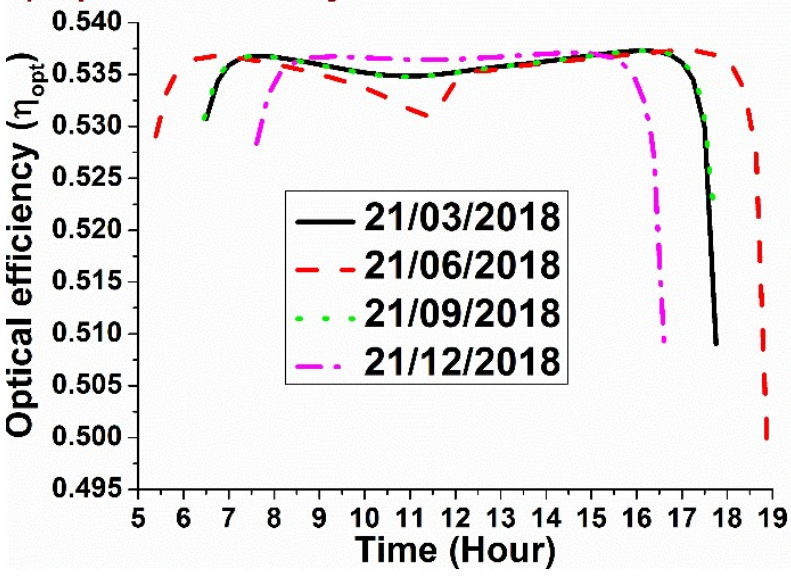




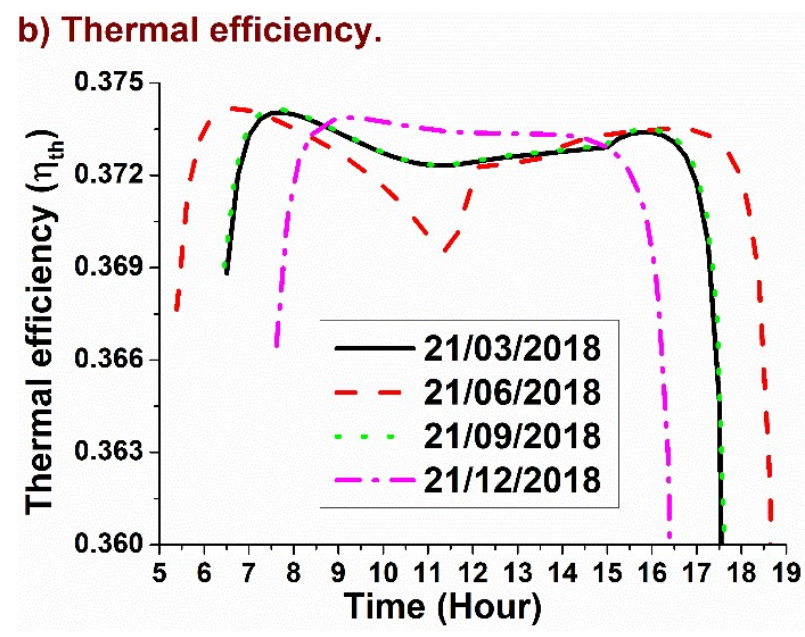

Fig. 3. Evaluate the performance of the studied solar collector: a) optical efficiency, b) thermal efficiency.

The optical efficiencies variation is very reasonable from sunrise to sunset. The average values of optical efficiencies for the four days starting March through December are as follows: $53.6 \%, 53.58 \%, 53.59 \%$, and $53.65 \%$. It can be said that the optical efficiency of the studied device is $53.60 \%$; these values are very significant for this kind of solar concentrator. As for thermal efficiency " $\eta_{\text {th }}$ ", it is related to the optical properties of linear Fresnel solar reflector components, related to heat loss around the receiver tube, and also relates to the intercept coefficient " $\gamma$ ". The thermal efficiencies variation is very rational from sunrise to sunset. The average values of thermal efficiencies for the four days starting March through December are as follows: $37.275 \%, 37.286 \%, 37.28$, and $37.33 \%$. It can be said that the thermal efficiency of the studied LFR solar collector is $37.30 \%$; these values are substantial for this kind of solar concentrator.

\subsection{Temperature estimation}

The modeled geometry is a tubular absorber, surmounted by a secondary reflector, forming a cavity closed by a glass plate in the lower part. The main objective of this work is to represent an analysis of thermal behavior of a linear Fresnel reflector, through this analysis, the different thermal exchanges within the receiver system were studied, namely: convective and radiative exchanges, also the temperature profiles across the different elements of the receiver system were studied, and finally the overall linear heat losses through the different surfaces of the receiver were estimated.

The receiver system usually consists of three basic components as follows:

- The absorber tube: it is a cylindrical tube, in which the heat transfer fluid (superheated steam) circulates. Its outer wall is absorbent. The absorber tube is usually surrounded by a special glass tube to reduce heat loss, which will allow to improve the efficiency of the Fresnel type solar collector.
- The secondary reflector: it is placed above the tube. It reflects on the tube, the solar radiation which enters the cavity.

- the glass, which closes the cavity below. It allows solar radiation to pass through, but blocks infrared radiation.

Knowing that the average mass flow of steam inside the receiver tube is $0.045 \mathrm{~kg} / \mathrm{s}$. The change in the temperature gradient between the absorbent tube, the steam, and the glass tube is directly affected by the weather conditions for each day.

Figs. 4(a-c) contain the change in the temperature of the receiver tube, the superheated steam, and the glass cover. For all days, the descending order of the temperatures is as follows " $\mathrm{T}_{\mathrm{Ab}},(\mathrm{K})$ ), "Т $\mathrm{T}_{\mathrm{HTF}},(\mathrm{K})$ ", and finally " $\mathrm{T}_{\mathrm{G}},(\mathrm{K})$ ". It is obvious to show that the variation of the temperatures depends particularly on the incident beam radiation and the surrounding climatic conditions. Figs. 4(a-c) show that:

- The superheated steam temperature changes from $501 \mathrm{~K}$ to $538.35 \mathrm{~K}$. The steam is in a superheated phase, where it can be used in the production of electricity in power plants that use Linear Fresnel solar concentrators; these stations are called the steam power plants. This station is called a concentrating thermodynamic solar power plant; it is a power plant that concentrates the direct sun's rays using flat mirrors to heat the steam that generally allows the production of electricity.

- The receiver tube temperature changes from $536.82 \mathrm{~K}$ to $620.93 \mathrm{~K}$.

- The glass cover temperature varies from $300.90 \mathrm{~K}$ to $364.88 \mathrm{~K}$. The glass cover is transparent to sunlight but opaque to the infrared rays of the interior, which traps the heat.

Table 3 contains a comparison of the results obtained by this study in terms of the days chosen to perform this numerical simulation.

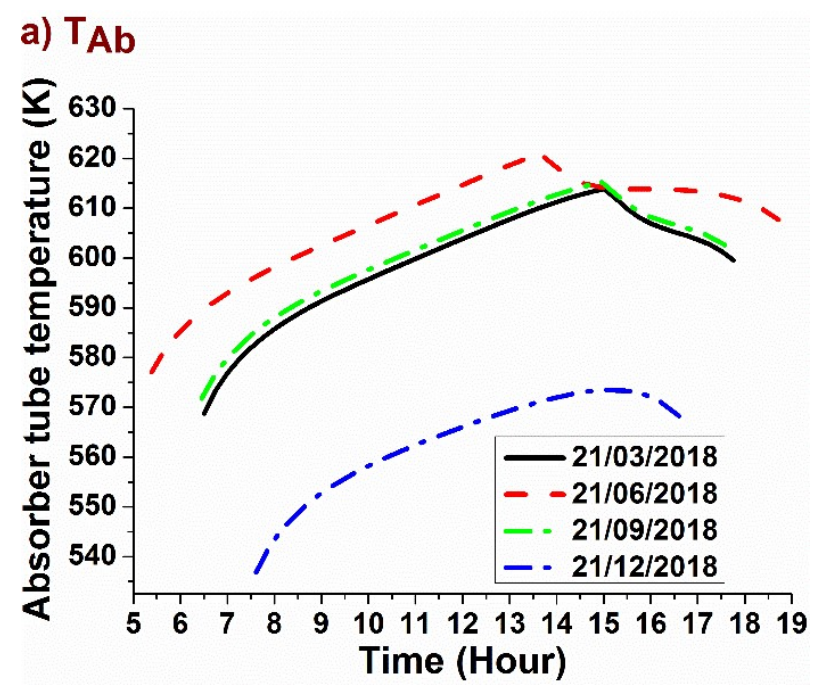




\section{b) THTF}

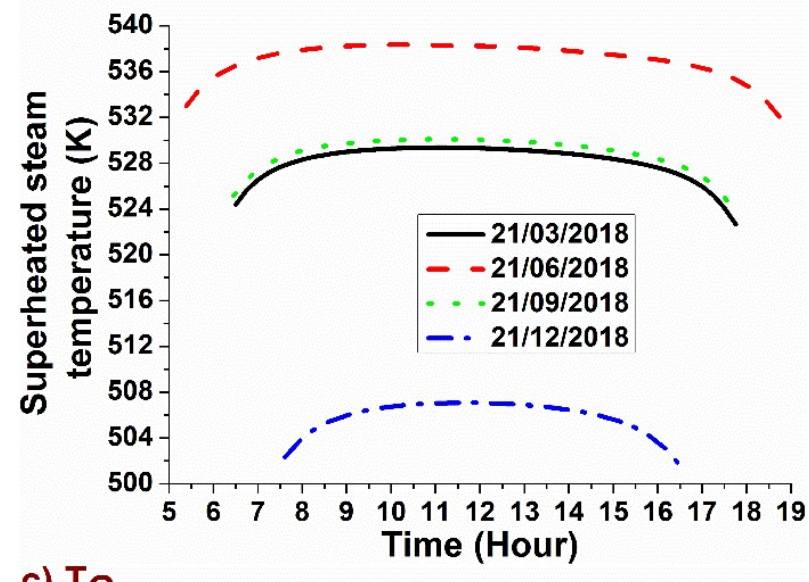

c) $\mathrm{T}_{\mathrm{G}}$

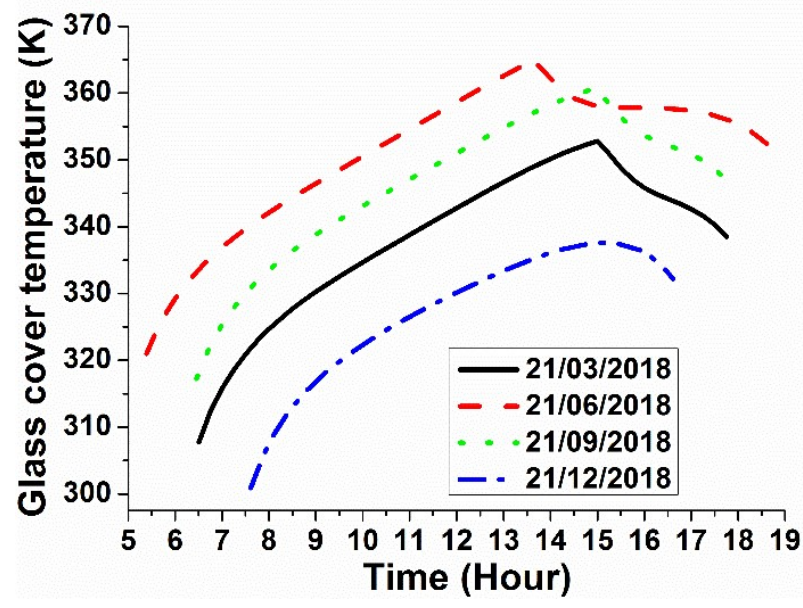

Fig. 4. The temperature change: a) $\left.\left.\mathrm{T}_{\mathrm{Ab}}, \mathrm{b}\right) \mathrm{T}_{\mathrm{HTF}}, \mathrm{c}\right) \mathrm{T}_{\mathrm{G}}$.

\subsection{The overall coefficient of heat loss}

The receiver tube is the seat of thermal losses. Generally, the vacuum between the receiver tube and the glass cover improves the insulation against convection losses. In addition, the lower value of the receiver tube emissivity generates an increase in the thermal efficiency of the studied reflector. Thermal loss is known as a very important parameter called the overall coefficient of heat loss " $\mathrm{U}_{\mathrm{L}},\left(\mathrm{W} / \mathrm{m}^{2} . \mathrm{K}\right)$ ". The thermal loss depending on the thermal insulation properties of the solar concentrator. Fig.5 shows the change in the overall coefficient of heat loss.

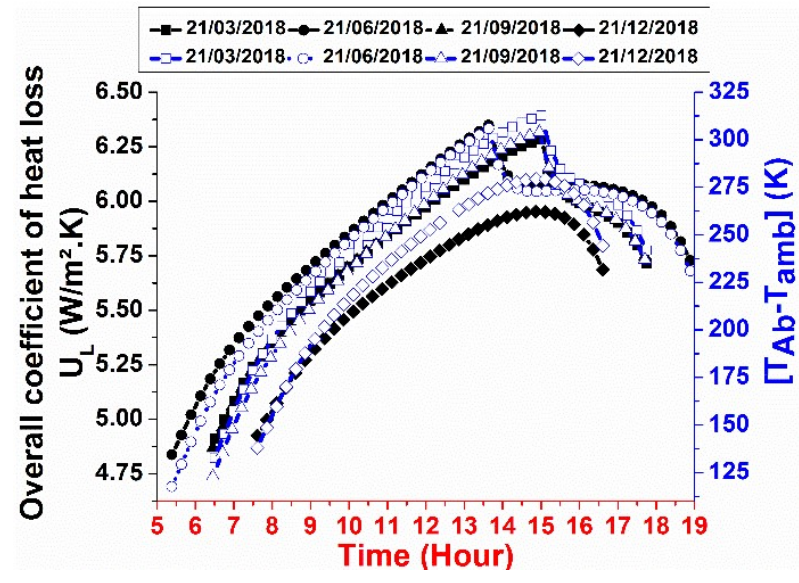

Fig. 5. Change in the overall coefficient of heat loss.
The average values of the overall coefficient of heat for the four days starting March through December are as follows: $5.885 \mathrm{~W} / \mathrm{m}^{2} . \mathrm{K}, 5.98 \mathrm{~W} / \mathrm{m}^{2} . \mathrm{K}, 5.89 \mathrm{~W} / \mathrm{m}^{2} . \mathrm{K}$, and $5.72 \mathrm{~W} / \mathrm{m}^{2} \mathrm{~K}$. As information, the use of a glass tube around the copper receiver tube can reduce the overall heat loss coefficient, where it can be said that the results obtained are very acceptable.

The numerical model which has been adopted to follow the energetic behavior of the heat absorption system (absorber tube) has shown that the radiative losses occur mainly almost exclusively at the level of the glass tube, therefore, the good control of the thermal losses depends mainly on the knowledge details of the properties of the different materials of the absorber tube of the studied solar collector.

Table 3. A comparison of the results of the study.

\begin{tabular}{|c|c|c|c|c|c|c|c|c|}
\hline & \multicolumn{2}{|c|}{$21 / 03 / 2018$} & \multicolumn{2}{|c|}{$21 / 06 / 2018$} & \multicolumn{2}{|c|}{$21 / 09 / 2018$} & \multicolumn{2}{|c|}{$21 / 12 / 2018$} \\
\hline & $\sum^{ \pm}$ & $\stackrel{\Xi}{\Sigma}$ & $\sum^{J}$ & 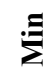 & $\sum^{E}$ & $\Xi$ & $\sum^{E}$ & $\stackrel{\Xi}{\Sigma}$ \\
\hline$\underset{\varepsilon}{2}$ & 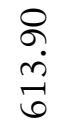 & $\begin{array}{l}\wp \\
\infty \\
\infty \\
0 \\
0\end{array}$ & $\begin{array}{l}\tilde{n} \\
\stackrel{0}{\sigma} \\
\tilde{\sigma}\end{array}$ & $\begin{array}{l}\text { J } \\
\text { N } \\
\text { in }\end{array}$ & 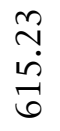 & $\stackrel{\infty}{\underset{N}{N}}$ & 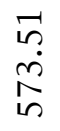 & $\begin{array}{l}\vec{\infty} \\
\dot{0} \\
m \\
\text { in }\end{array}$ \\
\hline$\underset{E}{E}$ & 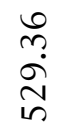 & 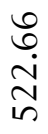 & $\begin{array}{l}n \\
n \\
\infty \\
n \\
n\end{array}$ & 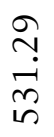 & $\begin{array}{l}0 \\
\stackrel{0}{0} \\
\text { m } \\
\text { in }\end{array}$ & $\begin{array}{l}\hat{\sigma} \\
\text { r. } \\
\text { N }\end{array}$ & $\begin{array}{l}1 \\
0 \\
0 \\
0\end{array}$ & ơ \\
\hline$\underset{2}{2}$ & $\begin{array}{l}\text { N } \\
\infty \\
\text { N } \\
m\end{array}$ & $\begin{array}{l}N \\
N \\
0 \\
\end{array}$ & $\begin{array}{l}\infty \\
\infty \\
\dot{t} \\
b \\
m\end{array}$ & $\stackrel{\vec{N}}{\text { n }}$ & 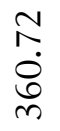 & $\begin{array}{r}N \\
\\
\end{array}$ & $\begin{array}{l}0 \\
\\
n \\
m\end{array}$ & $\begin{array}{l}\text { ஜ̊ } \\
\text { ஜ் } \\
\text { ஜ }\end{array}$ \\
\hline$\underset{\square}{\stackrel{4}{a}}$ & $\stackrel{\infty}{\stackrel{\infty}{0}}$ & $\begin{array}{l}\stackrel{0}{ت} \\
\sigma \\
\dot{\sigma}\end{array}$ & $\begin{array}{l}\infty \\
\stackrel{+}{+} \\
ٌ\end{array}$ & $\begin{array}{l}+ \\
\infty \\
\dot{\nabla}\end{array}$ & ?ִ & $\begin{array}{l}N \\
\infty \\
\dot{\sigma}\end{array}$ & $\begin{array}{l}\text { Rे } \\
\text { in }\end{array}$ & $\stackrel{\text { নे }}{+}$ \\
\hline 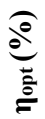 & $\begin{array}{l}n \\
\\
\end{array}$ & 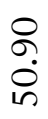 & $\begin{array}{l}n \\
\stackrel{n}{n}\end{array}$ & $\begin{array}{l}\vec{\infty} \\
\dot{\gamma}\end{array}$ & $\begin{array}{l}n \\
\stackrel{n}{n}\end{array}$ & $\begin{array}{c}\stackrel{ }{y} \\
\text { ก } \\
\text { ก }\end{array}$ & $\begin{array}{r}\vec{r} \\
\dot{n}\end{array}$ & $\begin{array}{l}+ \\
\infty \\
0 \\
0 \\
10\end{array}$ \\
\hline 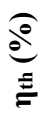 & $\begin{array}{l}\stackrel{0}{+} \\
\text { r. } \\
\text { m }\end{array}$ & $\begin{array}{l}n \\
\tilde{n} \\
\tilde{n}\end{array}$ & $\underset{\sim}{\stackrel{\sim}{*}}$ & $\begin{array}{l}0 \\
\text { రి } \\
\text { ñ }\end{array}$ & $\stackrel{\vec{r}}{\stackrel{r}{n}}$ & $\begin{array}{l}0 \\
\emptyset \\
i n \\
n\end{array}$ & $\begin{array}{l}n \\
n \\
n\end{array}$ & 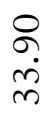 \\
\hline
\end{tabular}

The results obtained are very logical, as they are controlled by seasonal climatic conditions for each of the days chosen for this study.

Fig. 6 shows an illustrative diagram of the solar power station's duty cycle. This scheme contains the most 
important practical conditions for the station and is related to the linear Fresnel collector (pressure and temperature of the steam at the inlet and outlet of the receiver tube), where the steam pressure at the inlet of the receiver tube is equal to 58 bar.

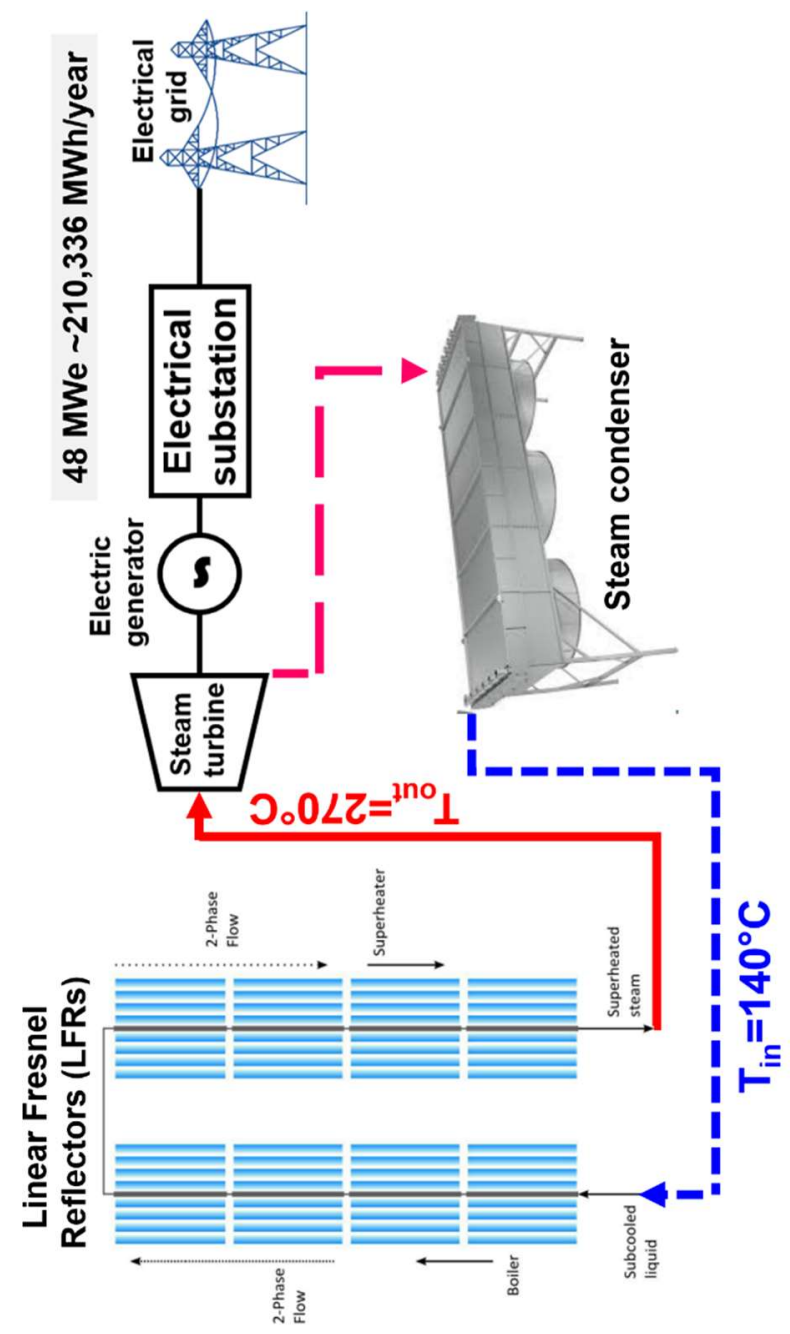

Fig. 6. An illustration diagram of the solar power plant's duty cycle [20].

\section{Conclusion}

Linear Fresnel solar thermal concentrators are devices designed to collect solar energy transmitted by direct solar radiation and communicate it to a heat transfer fluid in the form of heat. This heat energy can then be used for the production of electricity or in various industrial processes.

The optical efficiency of the device was estimated at $53.60 \%$, where the thermal efficiency is equal to 37.30 $\%$. As for the average values of the overall coefficient of heat loss, they were limited between $5.72 \mathrm{~W} / \mathrm{m}^{2} . \mathrm{K}$ and $5.98 \mathrm{~W} / \mathrm{m}^{2} . \mathrm{K}$.

Concerning steam, the temperature in December reached $501 \mathrm{~K}$. This is the lowest value recorded during the study. It is noted that the steam has exceeded the saturation phase, as it entered the superheated phase. The direct use of this superheated steam can produce electricity. This result is very encouraging to start with such investments.

The results obtained indicate that investment in this technology for electricity production is very successful.

\section{Nomenclature}

\begin{tabular}{|c|c|}
\hline $\mathrm{A}_{\mathrm{A}}$ & $\begin{array}{l}\text { Difference between the inner and the outer } \\
\text { surface of the absorber tube, } \mathrm{m}^{2}\end{array}$ \\
\hline $\mathrm{A}_{\mathrm{A}, \mathrm{ext}}$ & $\begin{array}{l}\text { The outside surface of the absorber tube, } \\
\mathrm{m}^{2}\end{array}$ \\
\hline $\mathrm{A}_{\mathrm{A}, \text { int }}$ & The inner surface of the absorber tube, $\mathrm{m}^{2}$ \\
\hline $\mathrm{A}_{\mathrm{G}}$ & $\begin{array}{l}\text { Difference between the inner and the outer } \\
\text { surface of the glass cover, } \mathrm{m}^{2}\end{array}$ \\
\hline $\mathrm{C}$ & An empirical factor, $1 / \mathrm{K}^{0.4} \cdot \mathrm{m}^{0.25}$ \\
\hline $\mathrm{Cp}_{\mathrm{A}}$ & Receiver tube specific heat, J/kg.K \\
\hline $\mathrm{Cp}_{\mathrm{F}}$ & Steam specific heat, J/kg.K \\
\hline $\mathrm{Cp}_{\mathrm{G}}$ & Glass cover specific heat, J/kg.K \\
\hline $\mathrm{D}_{\mathrm{A}, \mathrm{ext}}$ & $\begin{array}{l}\text { The outside diameter of the absorber tube, } \\
\mathrm{m}\end{array}$ \\
\hline $\mathrm{D}_{\mathrm{A}, \text { int }}$ & The inner diameter of the receiver tube, $\mathrm{m}$ \\
\hline $\mathrm{D}_{\mathrm{V}, \mathrm{ext}}$ & The outside diameter of the glass cover, $\mathrm{m}$ \\
\hline $\mathrm{D}_{\mathrm{V}, \text { int }}$ & The inner diameter of the glass cover, $\mathrm{m}$ \\
\hline DNI & Direct Normal Irradiance, $\mathrm{W} / \mathrm{m}^{2}$ \\
\hline $\mathrm{h}_{\mathrm{F}}$ & Steam Convection Coefficient, $\mathrm{W} / \mathrm{m}^{2} . \mathrm{K}$ \\
\hline hw & Wind convection coefficient, $\mathrm{W} / \mathrm{m}^{2} . \mathrm{K}$ \\
\hline $\mathrm{K}_{1}\left(\theta_{1}\right)$ & $\begin{array}{l}\text { Correction coefficient of incidence angle } \\
\text { in the longitudinal plane, }(-)\end{array}$ \\
\hline $\mathrm{K}_{\mathrm{t}}\left(\theta_{\mathrm{t}}\right)$ & $\begin{array}{l}\text { Correction coefficient of incidence angle } \\
\text { in the transverse plane, }(-)\end{array}$ \\
\hline $\mathrm{L}_{\mathrm{T}}$ & The total length of aperture area, $\mathrm{m}$ \\
\hline qabsorbed & Amount of energy absorbed by the tube, $\mathrm{W}$ \\
\hline$q_{\text {exit }}$ & $\begin{array}{l}\text { Amount of steam energy when leaving the } \\
\text { tube, } W\end{array}$ \\
\hline $\mathrm{q}_{\text {ext }}$ & External heat loss, W \\
\hline qgain & Energy gained by the steam, $\mathrm{W}$ \\
\hline $\mathrm{q}_{\text {int }}$ & Internal heat loss, $\mathrm{W}$ \\
\hline Qv & $\begin{array}{l}\text { Volumetric flow of vapor into the tube, } \\
\mathrm{m}^{3} / \mathrm{s}\end{array}$ \\
\hline $\mathrm{S}_{\mathrm{e}}$ & Effective reflective area, $\mathrm{m}^{2}$ \\
\hline $\mathrm{T}_{\mathrm{Ab}}$ & Receiver tube temperature, $\mathrm{K}$ \\
\hline $\mathrm{T}_{\mathrm{amb}}$ & The temperature of ambient air, $\mathrm{K}$ \\
\hline $\mathrm{T}_{\mathrm{G}}$ & Glass tube temperature, $\mathrm{K}$ \\
\hline $\mathrm{T}_{\mathrm{HTF}}$ & Steam temperature, $\mathrm{K}$ \\
\hline $\mathrm{W}_{\mathrm{T}}$ & Total width of aperture area, $\mathrm{m}$ \\
\hline \multicolumn{2}{|c|}{ Greek letters } \\
\hline$\gamma$ & Intercept factor, (-) \\
\hline$\tau$ & Glass tube transmittance, $(-)$ \\
\hline$\varepsilon_{\mathrm{Ab}}$ & Receiver tube emissivity, (-) \\
\hline$\varepsilon_{\mathrm{G}}$ & Glass tube emissivity, (-) \\
\hline$\alpha$ & Receiver tube absorptivity, (-) \\
\hline$\eta_{\text {opt }}$ & Optical efficiency, \% \\
\hline$\eta_{\text {th }}$ & Thermal efficiency, $\%$ \\
\hline$\rho_{\mathrm{A}}$ & The density of the receiver tube, $\mathrm{kg} / \mathrm{m}^{3}$ \\
\hline$\rho_{\mathrm{F}}$ & Steam density, $\mathrm{kg} / \mathrm{m}^{3}$ \\
\hline$\rho_{\mathrm{G}}$ & The density of the glass cover, $\mathrm{kg} / \mathrm{m}^{3}$ \\
\hline$\rho_{\mathrm{m}}$ & Mirror reflectance coefficient, (-) \\
\hline$\sigma$ & Stefan-Boltzmann constant, $\mathrm{W} / \mathrm{m}^{2} \cdot \mathrm{K}^{4}$ \\
\hline
\end{tabular}




\section{References}

1. Zhar, R., et al., Parametric analysis and multiobjective optimization of a combined Organic Rankine Cycle and Vapor Compression Cycle. Sustainable Energy Technologies and Assessments, 2021. 47: $\quad$ p. 101401. https://doi.org/10.1016/j.seta.2021.101401.

2. Ghodbane, M., et al., A numerical simulation of a linear Fresnel solar renector directed to produce steam for the power plant. Journal of Cleaner Production, 2019. 231: p. 494-508. https://doi.org/10.1016/j.jclepro.2019.05.201.

3. Attia, M.E.H., et al. Experimental Study of the Temperature Distribution Inside an Indirect Solar Dryer Chamber. in Advances in Air Conditioning and Refrigeration. 2021. Singapore: Springer Singapore.

4. Kalogirou, S.A., Performance of solar collectors, in Solar energy engineering : processes and systems. 2009, Academic Press of Elsevier. p. 219-250.

5. Kalogirou, S.A., Solar thermal collectors and applications. Progress in Energy and Combustion Science, 2004. 30(3): p. 231-295. https://doi.org/10.1016/j.pecs.2004.02.001.

6. Ghodbane, M., B. Boumeddane, and A.K. Hussein, Performance Analysis of a Solar-Driven Ejector Air Conditioning System Under El-Oued Climatic Conditions, Algeria. Journal of Thermal Engineering, 2021. 7(1): p. 172-189. https://dx.doi.org/10.18186/thermal.847334.

7. Ghodbane, M., et al., Thermal numerical investigation of a small parabolic trough collector under desert climatic conditions Journal of Thermal Engineering, 2021. 7(3): p. 429-446. https://doi.org/10.18186/thermal.884657.

8. Ghodbane, M., et al., Optical numerical investigation of a solar power plant of parabolic trough collectors. Journal of Thermal Engineering, 2021. 7(3): p. 550-569. https://doi.org/10.18186/thermal.888167.

9. Ghodbane, M. and B. Boumeddane, A parabolic trough solar collector as a solar system for heating water: a study based on numerical simulation International Journal of Energetica (IJECA) 2017. 2(2): $\quad$ p. 29-37. https://www.ijeca.info/index.php/IJECA/article/vie $\mathrm{w} / 32$.

10. Bellos, E., Z. Said, and C. Tzivanidis, The use of nanofluids in solar concentrating technologies: A comprehensive review. Journal of Cleaner Production, 2018. 196: p. 84-99. https://doi.org/10.1016/j.jclepro.2018.06.048.

11. Bellos, E. and C. Tzivanidis, A review of concentrating solar thermal collectors with and without nanofluids. Journal of Thermal Analysis and Calorimetry, 2019. 135(1): p. 763-786. https://doi.org/10.1007/s10973-018-7183-1.

12. Seyednezhad, M., et al., Nanoparticles for water desalination in solar heat exchanger. Journal of Thermal Analysis and Calorimetry, 2019: p. https://doi.org/10.1007/s10973-019-08634-6.
13. Ghodbane, M., et al., Performance assessment of linear Fresnel solar reaector using MWCNTs/DW nanonuids. Renewable Energy, 2020. 151: p. 43-56. https://doi.org/10.1016/j.renene.2019.10.137.

14. Hussein, A.K., et al., The Effect of the Baffle Length on the Natural Convection in an Enclosure Filled with Different Nanofluids. Journal of Thermal Analysis and Calorimetry, 2020: p. https://dx.doi.org/10.1007/s10973-020-10300-1.

15. Said, Z., et al., Recent advances on nanofluids for low to medium temperature solar collectors: energy, exergy, economic analysis and environmental impact. Progress in Energy and Combustion Science, 2021. 84: p. 100898. https://doi.org/10.1016/j.pecs.2020.100898.

16. Mahian, O., et al., Recent advances in using nanofluids in renewable energy systems and the environmental implications of their uptake. Nano Energy, 2021. 86: p. 106069. https://doi.org/10.1016/j.nanoen.2021.106069.

17. Ghodbane, M., et al., Brief on Solar Concentrators: Differences and Applications. Instrumentation Mesure Metrologie, 2020. 19(5): p. 371-378. https://dx.doi.org/10.18280/i2m.190507.

18. Said, Z., et al., Optical performance assessment of a small experimental prototype of linear Fresnel reflector. Case Studies in Thermal Engineering, 2019: https://doi.org/10.1016/j.csite.2019.100541.

19. Bellos, E., Progress in the design and the applications of Linear Fresnel Reflectors - A critical review. Thermal Science and Engineering Progress, 2019. 10(May 2019): p. 112-137. https://doi.org/10.1016/j.tsep.2019.01.014.

20. Ghodbane, M., et al., Energy, Financial and Environmental investigation of a direct steam production power plant driven by linear Fresnel solar reflectors. Journal of Solar Energy Engineering, Apr 2021. 143(2): p. 021008. https://doi.org/10.1115/1.4048158.

21. Bellos, E., C. Tzivanidis, and A. Papadopoulos, Enhancing the performance of a linear Fresnel reflector using nanofluids and internal finned absorber. Journal of Thermal Analysis and Calorimetry, 2019. 135(1): p. 237-255. https://doi.org/10.1007/s10973-018-6989-1.

22. Bellos, E., et al., Energy and financial investigation of a cogeneration system based on linear Fresnel reflectors. Energy Conversion and Management, $2019 . \quad 198$ : p. 111821. https://doi.org/10.1016/j.enconman.2019.111821.

23. Bellos, E., C. Tzivanidis, and A. Papadopoulos, Optical and thermal analysis of a linear Fresnel reflector operating with thermal oil, molten salt and liquid sodium. Applied Thermal Engineering, 2018. 133: $\quad$ p. $70-80$. https://doi.org/10.1016/j.applthermaleng.2018.01.0 38.

24. Bellos, E., C. Tzivanidis, and A. Papadopoulos, Daily, monthly and yearly performance of a linear Fresnel reflector. Solar Energy, 2018. 173(517-529. https://doi.org/10.1016/j.solener.2018.08.008). 
25. Barbón, A., et al., Theoretical elements for the design of a small scale Linear Fresnel Reflector: Frontal and lateral views. Solar Energy, 2016. 132( July 2016): p. 188-202. http://dx.doi.org/10.1016/j.solener.2016.02.054.

26. Barbón, A., et al., Optimization of the distribution of small scale linear Fresnel reflectors on roofs of urban buildings. Applied Mathematical Modelling, 2018. 59(July 2018): p. 233-250. https://doi.org/10.1016/j.apm.2018.01.040.

27. Barbón, A., et al., Parametric study of the small scale linear Fresnel reflector. Renewable Energy, 2018. 116(February 2018): p. 64-74. https://doi.org/10.1016/j.renene.2017.09.066.

28. Ghodbane, M., B. Boumeddane, and N. Said, Design and experimental study of a solar system for heating water utilizing a linear Fresnel reflector. Journal of Fundamental and Applied Sciences, 2016. 8(3): p. 804-825, http://dx.doi.org/10.4314/jfas.v8i3.8.

29. Ghodbane, M., B. Boumeddane, and N. Said, A linear Fresnel reflector as a solar system for heating water: theoretical and experimental study. Case Studies in Thermal Engineering, 2016. 8(C): p. 176186, http://dx.doi.org/10.1016/j.csite.2016.06.006.

30. Ghodbane, M., et al., Evaluating energy efficiency and economic effect of heat transfer in copper tube for small solar linear Fresnel reflector. Journal of Thermal Analysis and Calorimetry, 2021. 143(6): p. 4197-4215. https://doi.org/10.1007/s10973-02009384-6.

31. Said, Z., et al., Heat transfer, entropy generation, economic and environmental analyses of linear Fresnel reflector using novel rGO-Co3O4 hybrid nanofluids. Renewable Energy, 2021. 165(Part 1): p. 420-437. https://doi.org/10.1016/j.renene.2020.11.054.

32. Said, Z., et al., $4 E$ (Energy, Exergy, Economic, and Environment) examination of a small LFR solar water heater: An experimental and numerical study. Case Studies in Thermal Engineering, 2021. 27: p. 101277.

https://doi.org/10.1016/j.csite.2021.101277.

33. Ghodbane, M. and B. Boumeddane, Optical modeling and thermal behavior of a parabolic trough solar collector in the Algerian sahara AMSE JOURNALS-AMSE IIETA, MMC_B, 2017. 86(2): p. 406-426.

https://doi.org/10.18280/mmc_b.860207 